\title{
Development of Electric Bicycle Design for Middle School Students with Feminine Concepts
}

\author{
Bambang Tristiyono ${ }^{1}$ Bambang Iskandriawan ${ }^{1}$ Andhika Estiyono ${ }^{1}$ Arie \\ Kurniawan ${ }^{1}$ \\ ${ }^{1}$ Department of Product Design, Faculty of Creative Design and Digital Business, Institut Teknologi Sepuluh \\ November (ITS), Surabaya, Indonesia \\ *Corresponding author. Email: pakmbi@gmail.com
}

\begin{abstract}
Cycling to school makes energy drained and tired, especially if the distance to school is quite far approximately \pm 7-10 km, this problem becomes important because students should need excellent energy in following the learning process. This is often the reason why students are reluctant to cycle to school and parents also often cannot bear to allow their children to cycle long distances, especially female students. On the other hand life style becomes a problem for teenagers in every appearance, including bicycles that are used to school. But at this time, there is no special type of bicycle that fits the character of middle and high school adolescents, can be used multifunctionally, can be stylish, safe and comfortable to go to school. In terms of business opportunities, middle school adolescents are a large and potential market for the national bicycle industry. Data from the Ministry of Education and Culture of the Republic of Indonesia states that currently the number of students spread throughout Indonesia reaches more than 58 million people. This phenomenon has the potential to become a promising business opportunity at present and in the future, especially for local bicycle SMEs, given the competition in the national bicycle industry is still open. This research aims to produce a prototype of the first generation Feminine E-bike product. This research resulted in an exploration of electric bicycle designs that fit the needs of female students (style, self-actualization, safety and practical), solved the problem of how to carry a lot of school supplies, do not make dirty clothes, not tiring and competitive prices.
\end{abstract}

Keywords: Electric Bicycle, Middle School, Girl Student, Feminine e-bike, Local Bicycle SMEs.

\section{INTRODUCTION}

Bicycles are still one of the preferred modes of transportation because they are cheap and more environmentally friendly [1]. This means of transportation is not only effectively used for schooling, but also for other needs, for example following extracurricular activities, tutoring, playing, relaxing biking, or exercising a bicycle. Adolescents of middle and high school are big and potential markets for the national bicycle industry. Based on BPS data $2017 / 2018$, the number of junior high school students reached 10.13 million $(22.35 \%)$. While students for senior high schools (SMA) reached 4.78 million people $(10.56 \%)$ and for vocational high schools (SMK) as many as 4.9 million people (10.83\%) [2]. The number is a very interesting business potential to be developed, while the national bicycle industry competition is still not tight.

The current condition as much as $39 \%$ of national bicycle demand is met by three domestic producers, namely Wim Cycle produced by PT Wijaya Indonesia Makmur; Polygon produced by PT Insera Sena; and United Bike produced by PT Terang Dunia Internusa. While $11 \%$ of other domestic fulfillments are filled with home industry products. In data, in 2012 bicycle demand has reached 7.2 million units. The demand jumped from 5 million units in the middle of the previous two years [3]. Seeing this picture, it is very clear that the market for the bicycle industry is still very open, especially for bicycle SMEs to compete in meeting the high demand of the market. The national 
bicycle market is spread from the age of children, adolescents, adults, to parents with a variety of needs and functions of each.

Another interesting phenomenon is that many high school students use motorbikes to school, even though they do not have a SIM C. According to Law No.22 of 2009 articles $77 \& 81$, it is stated that motorcycle drivers must have a driving license (SIM C) that can obtained at the minimum age of 17 years. But the rampant enforcement of the road apparatus apparently does not make the number of child riders shrink, said the Head of the Law Enforcement Division of the National Police Traffic Corps, Police Commissioner Indrajit. "We have taken 290,068 cases, that's only six months, while last year we took 607 children per 90 thousand students," Indrajit exclaimed. That means that throughout the year alone there are more than 1600 school students every day, from elementary to high school level, who are subject to police sanctions for driving without having a SIM [4].

Some previous research on electric bicycles [5] [6] [7] be a reference in the development of this research. F. Sodiq and B. Tristiyono [5], has conducted research on the Design of Electric Bicycles for Housewives as a Daily Means of Transportation that Can Be Produced by Local SMEs, which aims to develop environmentally friendly transportation facilities, given the increasing air pollution. Next is M. Huda and B. Tristiyono [6], developing an Electric Bike Design for Middle School \& High School Children who Support Urban Youth Lifestyle Activities, the research is concerned with environmentally friendly transportation and the lifestyle of city adolescents who like to cycle with male teenagers. The design development of electric bicycles for teens targeting unisex has been done by Tristiyono et.al [7], the selection of electric motors on the hub (hub-motor) is very interesting so that the design is more stylish.

In this research design exploration will be carried out to meet the needs of adolescents in cycling (style, self- actualization, practical and economical), solving existing problems (how to carry a lot of school needs, safe not to pollute clothing, not tiring, can become a substitute for a motorcycle) and competitive prices in the market.

\section{DESCRIPTION OF PROBLEMS \& REQUIREMENTS}

From the background explanation above, it can be identified several problems that will be resolved into bicycle business solutions going forward with the target of middle and high school adolescents as follows:

(1) Problems with bicycle storage; the existing bicycle storage is not sufficient to carry a lot of school supplies (sports shoes, change clothes, food supplies, extra books, etc.) so that the bicycle is unable to accommodate the luggage of so many middle and high school students, while the existing bicycle designs (BMX, MTB, City Bike, Race Bike, PIXY, Folding
Bike) are not specific to those needs

(2) Safety issues from the risk of clothes becoming dirty especially in the rainy season (many bicycles are not equipped with safe 'fenders') and clothes that are pinched chained so that they become dirty because of insufficient chain protectors. This problem is very disturbing middle and high school students, because it makes them embarrassed at school with dirty clothes, this is also a cause of students reluctant to go to school.

(3) Cycling makes energy drained and tired, especially if the distance to school is quite far $( \pm 7-10$ $\mathrm{km})$, this problem becomes important because students should need excellent energy in following the learning process at school.

(4) Problems of adolescent life style in cycling. This problem turned out to be very important in the current era of modern times, many teenagers who do not want to go biking to school because the type of bicycles that do not match the mood and taste. Adolescence is a time of transition in search of identity and style in every appearance, every accessory used should be able to support its appearance, including bicycles that are used to school.

\section{METHOD}

The method used in this study: (1) Field Observation Method (2) Questionnaire Method (3) Integrated Digital Design Method (4) Product Prototyping Method.

\subsection{Field Observation Method:}

Conduct field observations on related research partners. It is very important to understand the situation and conditions that actually occur in the field, related to the problems that occur, the needs that are important to be developed, and the trends that are developing at this time for future planning.

\subsection{Questionnaire Method:}

This method is very suitable because the respondents are difficult to collect at the same time, limited research time, and limited research staff while the data required is very much. Consumer research is carried out by distributing questionnaires directly. The intended respondent is middle school adolescents. Middle school adolescence is 13-17 years.

\subsection{Integrated Digital Design Method [8]:}

Digital Design Method is applied to the design of high- precision products based on digital technology to improve quality through accurate digital processes and simulations in terms of size, material, and photorealistic rendering. Facilitate and accelerate the design process at the concept stage, initial design, and design development to the digital prototyping stage, which significantly reduces lead time at the production stage. The results obtained can be used as a marketing medium for product communications in the form of printed goods, virtual showcases, website content, ecatalogs, and so on. 


\subsection{Product Prototyping Method:}

Making product samples like the original (prototype), which allows real simulations to assess product quality based on consumer responses. The results of consumer assessment as material for design improvement for the final prototype so that product validity is increased so that the risk of failure is minimal. More real and accurate because consumers can try directly and feel the real conditions.

\section{DESIGN CONCEPT \& ANALYSIS}

The following is a description of the design concept and analysis in this research.

\subsection{Consumer Psychographic Analysis:}

Psychographic analysis produces design needs based on AIO (activity, interest, opinion) of target consumers. The target consumers are middle school students, especially women, aged 13-17 years. From the questionnaire and interview conducted, it can be concluded that the activities include: school, play, extracurricular, group work, sports, to the market. Interests include; functional objects, novelties, attractive appearance, stylish, practical, simple. Opinion includes: being interested in new things, style is important, the value of the function must be considered, simple and elegant, trendy. The conclusion of the psychographic analysis, school bicycle design needs, are: something of character, price according to quality, value of function, minimal maintenance, longlasting, trend in the era, practical, stylish.

\subsection{Objective Tree Concept:}

The design concepts derived from brainstorming and the idea process are formulated in concept keywords. There are 3 concept keywords, namely: compact design, feminine style, and local production.

Compact design includes: clear appearance and multifunction. Clear appearance is manifested in the design of the covering body and chain, simple fenders, hidden wiring. Multifunction is realized in the storage design that functions for bags \& shoes containers and others.

Feminine style includes: feminine frame and fit with women. Feminine frames are embodied in designs in soft design styles and colors. Fit with women is manifested in lower top tube and character form, organic \& curved designs.

Local production is implemented in local SMEs technology which includes: production, finishing and assembly are carried out all at local SMEs.

\subsection{Overview of Electric Bicycle Components:}

Electric bicycles have several main components to be able to run it, these components are: electric motors, batteries, controllers, and chargers, in addition to that there is one more important tool that is monitoring tools.

\section{Electric motor.}

The driving motor or also can be called a dynamo is a component that functions to produce power rotation movements to drive a bicycle [9]. The electric motor is a brushless DC (BLDC) motor. There are various types of motorbikes available, depending on their placement on the bicycle. Large voltage is available ranging from 24 to 48 volts, while for large electrical power is available from 250 to 1200 watts. The thing to note when installing a motorbike on an electric bicycle is the difference in current between the battery and the motorbike. If it is installed upside down, the bicycle will run backwards. Type of Electric Motor used is the type of brushless rear hub motor. Working with $24 \mathrm{v}$ electricity running with throttle. This rear hub was chosen because of its easy installation system, low cost and easy to maintain. A motor with a 250 watt $24 \mathrm{~V}$ power can make a maximum bike speed of $35 \mathrm{~km} /$ hours with a maximum user weight of $100 \mathrm{~kg}$ and can store power as far as $12 \mathrm{~km}$.

2. Battery.

Batteries on electric bicycles are a very dominant component in maintaining the speed of a bicycle. Types of batteries available on the market usually have a cylindrical shape, pouch, or box [10]. The types of batteries used include: lead acid, $\mathrm{NiCd}, \mathrm{NiMH}$ and $\mathrm{Li}$ ion batteries. The types of batteries used for research are: 350 watt $24 \mathrm{~V}$ lead acid, due to low cost considerations.

\section{Controller.}

Electric bicycle controllers are generally only divided into a few types, namely standard controllers, full-featured controllers, LED / LCD function controllers, and sinewave controllers. [9]. The controller is the brain of an electric bicycle. Serves to regulate the distribution of current and voltage from the battery to the motor. Some controllers have a programming function so that the amount of current to the motor can be adjusted as needed.

4. Chargers

Chargers are used to charge batteries that have run out. So that it can be reused.

\section{Monitoring tool}

An important additional tool on an electric bicycle. Serves as info on the status of electric bicycle conditions. Starting from the speed, distance, up to the amount of current and voltage in realtime and the capacity of the battery that has been used.

\subsection{Posture and Bicycle Geometry Studies:}

According to Wilhelm Humpert in Kholilah, S., Tristiyono, B., \& Susandari, H. [11] There are three bike driving postures namely all round, tracking, and sport. First the upright body position, the second half bent (medium), the third position fully bent. Each has advantages and disadvantages. This position is strongly influenced by the frame geometry and is also influenced by the height of the post post, adjustable saddle, stem length and handle bar models. The choice of standard percentiles of a person's body size also 
greatly influences the posture of cycling. $95 \%$-tile is used when the design requires a looseness of size, $5 \%$ tile is used when the design size requires many people to reach. $50 \%$-tile is used for design sizes that do not work for clearances and reach.

The following is the relationship between anthropometric measurements with the operational dimensions of electric bicycles as a result of this research.

(1) Ankle height to hip / 750mm / 5\% -tile corresponds to saddle height from ground / $750 \mathrm{~mm}$.

(2) Hips to ankles fold position / 370mm / 50\% -tile in accordance with the saddle to pedal position upwards / 376mm.
(3) Shoulder to palm / 453mm / 5\% -tile corresponds to the saddle distance to handlebar / $453 \mathrm{~mm}$.

(4) Hip height / $656 \mathrm{~mm} / 5 \%$-tile corresponds to the height of the battery box from the ground / $590 \mathrm{~mm}$.

(5) Knee height / 380mm / 5\% -tile corresponds to the bottom frame height $/ 380 \mathrm{~mm}$.

\section{RESULT \& DISCUSSION}

\subsection{Alternative Design Sketches}

Following is a selection table of three alternative design sketches produced:

Table 1 Selection of Design Alternatives

\begin{tabular}{|l|l|l|l|l|l|l|l|l|l|}
\hline No & Parameter & Weight & Alternative 1 & Alternative 2 & Alternative 3 \\
\hline 1 & Care & Resigns Alternative 1 & Q1 & R1xW & R2 & R2xW & R3 & R3xW \\
\hline 2 & Styling & W & 0.1 & 2 & 0.2 & 3 & 0.3 & 2 & 0.2 \\
\hline 3 & Security & 0.15 & 2 & 0.3 & 2 & 0.3 & 3 & 0.45 \\
\hline 4 & Ergonomic Female Frame & 0.3 & 2 & 0.6 & 3 & 0.9 & 2 & 0.6 \\
\hline 5 & $\begin{array}{l}\text { Operating System Remove the } \\
\text { Battery }\end{array}$ & 0.2 & 2 & 0.4 & 2 & 0.4 & 3 & 0.6 \\
\hline 6 & Bicycle Weight & 0.15 & 3 & 0.45 & 4 & 0.6 & 2 & 0.3 \\
\hline & Total & 1 & & 2 & 0.2 & 2 & 0.2 & 2 & 0.2 \\
\hline
\end{tabular}

Note: $\mathrm{W}=$ weight, $\mathrm{R}=$ rate. Rating assessment with a range of interval scale of $1-5,1=$ lowest rating, $5=$ highest value. 
Table 2. Description of parameter weights

\begin{tabular}{|c|c|c|}
\hline $\begin{array}{c}\text { Alternative } \\
1 \\
\end{array}$ & $\begin{array}{c}\text { Alternative } \\
2 \\
\end{array}$ & $\begin{array}{c}\text { Alternative } \\
3 \\
\end{array}$ \\
\hline $\begin{array}{l}\text { Parameter 1: get a value of } 2 \\
\text { because bicycle maintenance is } \\
\text { quite easy Parameter } 2 \text { : gets a value } \\
\text { of } 2 \text { because of the usual style } \\
\text { Parameter 3: gets a value of } 2 \\
\text { because the security is quite good } \\
\text { protected from dirty splashes } \\
\text { Parameter 4: got a value of } 2 \text { because } \\
\text { it is quite in accordance with the } \\
\text { concept of feminine } \\
\text { Parameter 5: get a value of } 3 \\
\text { because it's easy to remove the } \\
\text { battery Parameter 6: gets a value of } \\
2 \text { because the bicycle's weight is } \\
\text { quite heavy }\end{array}$ & $\begin{array}{l}\text { Parameter 1: get a value of } 3 \\
\text { because bicycle maintenance is easy } \\
\text { and easy Parameter } 2 \text { : gets a value } \\
\text { of } 2 \text { because of the usual style } \\
\text { Parameter 3: gets a value of } 3 \\
\text { because good security is protected } \\
\text { from dirty splashes } \\
\text { Parameter 4: got a value of } 2 \text { because } \\
\text { it is quite in accordance with the } \\
\text { concept of feminine } \\
\text { Parameter 5: got a value of } 4 \text { because } \\
\text { it is very easy to remove the battery } \\
\text { Parameter 6: gets a value of } 2 \\
\text { because the bicycle's weight is quite } \\
\text { heavy }\end{array}$ & $\begin{array}{l}\text { Parameter 1: get a value of } 2 \\
\text { because bicycle maintenance is } \\
\text { quite easy Parameter } 2 \text { : get a value } \\
\text { of } 3 \text { because of the attractive style } \\
\text { and interest of adolescents } \\
\text { Parameter } 3 \text { : gets a value of } 2 \\
\text { because the security is quite good } \\
\text { protected from dirty splashes } \\
\text { Parameter } 4 \text { : get a value of } 3 \text { because } \\
\text { it is in accordance with the concept of } \\
\text { feminine } \\
\text { Parameter } 5 \text { : gets a value of } 2 \\
\text { because it's not easy to remove the } \\
\text { battery Parameter } 6 \text { : gets a value of } \\
2 \text { because the bicycle's weight is } \\
\text { quite heavy }\end{array}$ \\
\hline
\end{tabular}

Conclusion:

Alternative 2 was chosen based on the results of the highest number of parameters (2.7) because it has easy maintenance, attractive style, safety of splashed water, according to the feminine concept, ease of removing the battery and quite heavy weight.

\section{Design Development}

Here are the results of design development:

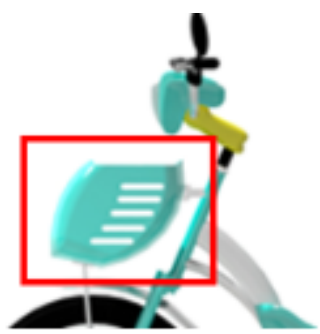

Figure 1 Storage Design

The storage design looks stylish, with a non-rigid shape, located in front of the head tube. This storage serves to place a lot of school luggage, such as: Sports shoes, change of clothes, textbooks, and so on.

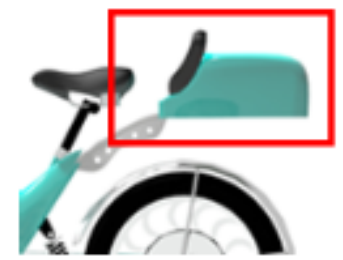

Figure 2 Battery Protector Cover

Battery Protective Cover serves to protect the battery to be safe from theft and safety. Removable plug for easy charging and maintenance. Shape looks styles, not rigid, integrated with the design.
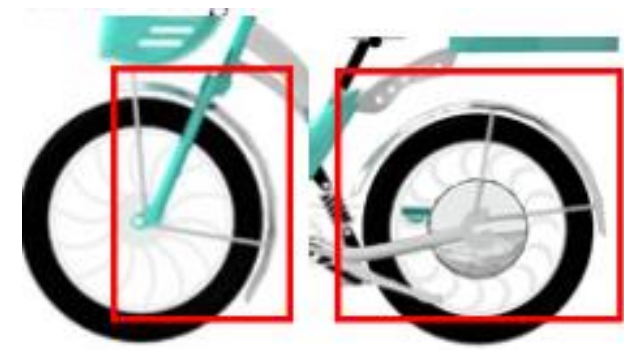

Figure 3 Fender Design

Fenders are designed to protect from wheel dirt. Simple design, very curvilinear feminism. Chrome finishing to add an elegant impression.

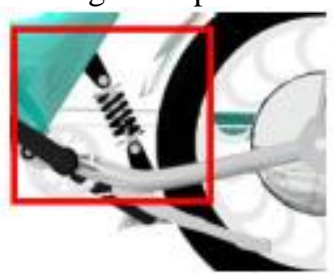

Figure 4 Suspension Design

Mono shock model rear suspension design. Serves to increase comfort so it is not too loud and reduce vibration from the wheels. The suspension is installed between the holder of the chain stay holder and the seat tube (seems simple does not interfere with the appearance of the bicycle).

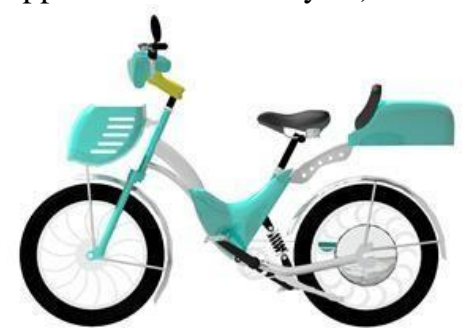

Figure 5 Overall design, Side View 
The overall design appearance, is a combination of curved shapes to create a feminine impression [6]. Low bottom tube design, curved downward as the main structural frame signifies the feminine concept. The form of other components (storage, battery cover, cover frame, fender), looks harmonious with the shape of the curve and not stiff.

\subsection{Product Branding}

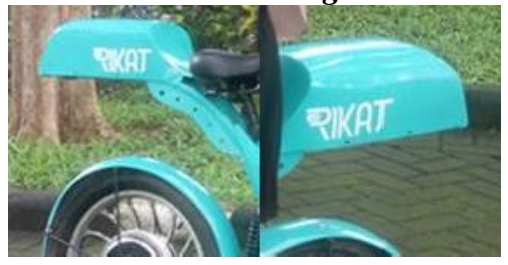

Figure 6 E-RIKAT Product Branding

The brand used is e-RIKAT, derived from the Javanese language RIKAT, which means fast and not lazy. Intended so that consumers who use these bikes can be delivered quickly to their destination, not lazy and immediately complete their work. RIKAT the popular and easy to remember word, the lowercase "e", in front of the word RIKAT, as the initial "electric" which means this electric- powered bicycle.

\section{CONCLUSION}

Some things that are the conclusions in this research are:

(1) The design concepts developed are concise design, feminine style, and local production.

(2) Mono shock model rear suspension design. Serves to increase comfort so it is not too loud and reduce vibration from the wheels. Suspension is placed between the chain stay holder and seat tube, to support the shape style.

(3) The battery and controller are placed behind the saddle, given a protective cover to protect the battery to be safe from theft and safety. Removable plug for easy charging and maintenance. Shape looks styles, not rigid, integrated with the design

(4) Fenders are designed to protect from wheel dirt. Simple design, very curvilinear feminism. Chrome finishing to add an elegant impression.

(5) Storage design looks stylish, with a non-rigid shape, located in front of the head tube. This storage serves to place a lot of school luggage, such as: Sports shoes, change of clothes, textbooks, and so on.
(6) The final technical specifications of the eRIKAT design are the main material: ERW (welded pipe) steel pipe, motor: rear brushless hub $24 \mathrm{~V} 12 \mathrm{~A}$, battery: 350 watt $24 \mathrm{~V}$ lead acid, maximum speed: $35 \mathrm{~km}$ / hour, mileage: $20 \mathrm{~km}$, wheel size: 20 ", max. load: $100 \mathrm{~kg}$, net weight: $20 \mathrm{~kg}$, supporting accessories: LED head lamp, battery voltage monitor.

\section{ACKNOWLEDGMENT}

This research was funded by the Directorate of Research and Community Service, Sepuluh November Institute of Technology, Ministry of Education and Culture, in accordance with the 2020 ITS Fund Prototype Research Implementation Agreement, Number: 873 / PKS

/ ITS / 2020, April 2, 2020.

\section{REFERENCES}

[1] L. Susanti and Y. H. Agustion, "Perancangan Konfigurasi Tinggi Setang, Sadel, dan Pedal Sepeda Yang Ergonomis," Jurnal Optimasi Sistem Industri, vol. 14, no. 1, pp. 33-38, April 2015.

[2] Databoks, "Berapa Jumlah Peserta Didik Indonesia?," databoks.katadata.co.id, (C2020 Katadata, 24 June 2019. [Online]. Available: https://databoks.katadata.co.id/datapublish/201 9/ 05/02/berapa-jumlah-peserta-didik indonesia. [Accessed 16 July 2020].

[3] WE.co.id, "Wim Cycle, Polygon, dan United Bike Kuasai 39\% Pasar Sepeda Indonesia," Warta Ekonomi.co.id, 4 August 2013. [Online]. Available: https://www.wartaekonomi.co.id/read14461/wi m-cycle-polygon-dan-united-bike-kuasai-39pasar- sepeda-indonesia. [Accessed 18 july 2020].

[4] D. Safitri, "1.600 pelajar tanpa SIM ditilang tiap hari," BBC New Indonesia, 11 September 2013. [Online]. Available: https://www.bbc.com/indonesia/berita_indones ia/2013/09/130911_underagebiker.shtml. [Accessed 17 July 2020].

[5] F. Sodiq and B. Tristiyono, "Desain Sepeda Listrik Untuk Ibu Rumah Tangga Sebagai Sarana Transportasi Sehari-hari Yang Dapat Diproduksi UKM Lokal," Jurnal Sains dan Seni ITS, vol. IV,no. 2, pp. F93-F96, 2015. Available: 